\title{
OBRAZ DUSZPASTERSTWA POLSKOJEZZYCZNEGO W EUROPIE NA PODSTAWIE WIZYTACJI REKTORA POLSKIEJ MISJI KATOLICKIEJ W BELGII
}

Polska Misja Katolicka (dalej: PMK), od chwili jej powołania w Belgii była ośrodkiem kierowniczym tak dla duszpasterstwa polskojęzycznego, jak i dla organizacji wychodźczych w tym krajuㄹ. Stwarzało to szerokie możliwości wpływu ideowego na wychodźstwo polskie oraz pozwalało podejmować jej kierownikowi - rektorowi wiele inicjatyw społecznych, integrujących rodaków. Obejmowały one wówczas m.in. organizowanie: szkolnictwa polskiego ${ }^{2}$, organizacji samopomocowych, poradnictwa prawnego, działalności charytatywnej, kulturalnej ${ }^{3}$. Wobec Kościoła katolickiego w Belgii, Holandii i Danii, PMK reprezentowała interesy Polaków. Decydujące znaczenie miała w tym względzie osoba rektora, który z racji prestiżu, jaki wiązał się z tym urzędem, spełniał rolę lidera wychodźstwa polskiego. Właśnie wtedy, kiedy kształtowały się podstawy prawne umożliwiające tworzenie szkolnictwa polskiego, zasadniczą rolę w jego organizowaniu odegrał rektor. Pełniony urząd, jak i osobiste kontakty z dyrekcjami kopalń, fabryk subsydiujących działalność ośrodków duszpasterstwa polskiego ułatwiały mu to zadanie. Do wyznaczenia odpowiedniego kapłana, na rektora PMK i jej zorganizowania w Belgii, zobowiązał prymas Polski rektora PMK we Francji - ks. Wilhelma Szymbora ${ }^{4}$ - spośród polskich duszpasterzy we Francji ${ }^{5}$. W odpowiedzi

* Ks. JózefSzymański-drhistorii Kościoła, adiunktw Ośrodku Badańnad Poloniąi Duszpasterstwem Polonijnym KUL.

${ }^{1}$ J. Szymański, Początki Polskiej Misji Katolickiej w Belgii, „Roczniki Teologiczne”, 52 (2005) z. 4, s. 85-105.

${ }^{2}$ Tenże, $Z$ dziejów szkolnictwa polonijnego $w$ Belgii $w$ okresie międzywojennym, „Studia Polonijne", 25 (2004) s. 103-124.

3 Tenże, Życie organizacyjne wychodźstwa polskiego $w$ Belgii $w$ okresie międzywojennym, „Studia Polonijne”, 26 (2005), s. 29-75.

${ }^{4}$ Tenże, Duszpasterze Polonii i Polaków za granica, t. 1, Lublin 2010, s. 141-144.

${ }^{5}$ Archiwum Archidiecezjalne w Gnieźnie (dalej: AAG), Archiwum Prymasa Polski (dalej: APP), Akta Protektora Wychodźctwa Polskiego (dalej: APWP), Belgia - Generalia, Dział III, Vol. 
tenże napisał, że „zrobi wszystko, aby w Belgii zapewnić duszpasterstwo"6. Sprawa się jednak komplikowała pomimo ponagleń ze strony Ministerstwa Spraw Zagranicznych. Prymas E. Dalbor wyjaśniał, że: „Sprawa duszpasterstwa Polaków w Belgii jest nieustanną troską moją. Na terenie belgijskim znajduje się około 5000 Polaków zorganizowanych w małych grupach. Wobec tego zorganizowanie dla nich odpowiedniej opieki duszpasterskiej jest tylko ta możliwość, aby ksiądz Polak osiadł na stałe w Brukseli i stąd objeżdżał regularnie kolonie polskie wedle planu ułożonego"7. Decyzję o powołaniu PMK w Brukseli ks. prymas podjął W styczniu 1926 r. $^{8}$, a zorganizowanie jej i opiekę duszpasterską nad Polakami ${ }^{9}$ powierzył ks. dr Tadeuszowi Kotowskiemu ${ }^{10}$. Rektora i księży kapelanów mianował prymas Polski w porozumieniu z episkopatem belgijskim. Działalność PMK obejmowała terytorium całej Belgii ${ }^{11}$. Odtąd PMK organizowała stałe dojazdy księży kapelanów do większych ośrodków robotniczych ${ }^{12}$. Jak zauważył rektor w piśmie do prymasa: „Misja jest zarzucana rezolucjami różnych kolonji polskich, domagających się ode mnie powiększenia dojazdów i bardziej stałej opieki duszpasterskiej"13.

Niemniej rektor PMK w Belgii zwrócił się do ks. prymasa z prośbą o rozszerzenie „działalności Misji w Belgii na Holandję i Danję. De facto sprawami duszpasterstwa tych 2-ch krajów Polska Misja Katolicka już się zajmuje, - gdyby Jego Eminencja formalnie uznał za wskazane to usankcjonować - uzyskałbym

I/44a, Charge d' Affaires a.i. Poniński, Do Jego Ekscelencji Księdza Kardynała Edmunda Dalbora, Arcybiskupa Prymasa Gnieźnieńsko-Poznańskiego, Pałac Biskupi, Poznań, Bruksela, 24.IX.1924.

${ }^{6}$ AAG, APP, APWP, Belgia - Generalia, Dział III, Vol. I/44a, X. Szymbor, Wasza Eminencjo!, Paris 6. 101924.

${ }^{7}$ AAG, APP, APWP, Belgia - Generalia, Dział III, Vol. I/44a, Koncept odpowiedzi prymasa, Do Ministerstwa Spr. Zagr. Departament Konsularny. Wydział ogólny w Warszawie.

${ }^{8}$ Polska Misja Katolicka w Belgji, „Biuletyn Komitetu Opieki Kulturalno - Społecznej dla Wychodztwa Polskiego w Belgji”, lipiec - sierpień 1926, s. 3; Polska Misja Katolicka w Belgji, Danji i Holandji, „Biuletyn Katolików Polskich w Belgji, Danji i Holandji”, 8/12 1927, s. 1.

${ }^{9}$ AAG, APP, APWP, Belgia - Generalia, Dział III, Vol. I/44a, Bp. Piotr [Mańkowski], Do Jego Eminencji Najprzewielebniejszego Księdza Kardynała Prymasa E. Dalbora w Poznaniu, Włodzimierz, dnia 16 stycznia 1926 r. Nr.36; Ks. Tadeusz Kotowski, Do Jego Eminencji Najdostojniejszego Xiędza Metropolity Gnieźnieńsko-Poznańskiego, Prymasa Polski, Protektora Polskich Misji Zagranicznych, Raport z działalności Pol. Misji Kat. w Belgji od 15-I. do 15-X. 1926 r.; Ks. J. Bakalarz, Kard. August Hlond - prekursor nowoczesnego apostolatu emigracyjnego, „Studia Towarzystwa Chrystusowego dla Polonii Zagranicznej”, 2 (1989) s. 63-64.

${ }^{10}$ Szymański, Duszpasterze Polonii i Polaków za granica, s. 72-74.

${ }^{11}$ AAG, APP, APWP, Belgia - Generalia, Dział III, Vol. I/44a, Ks. Tadeusz Kotowski, Do Jego Eminencji Najdostojniejszego Xiędza Metropolity Gnieźnieńsko-Poznańskiego, Prymasa Polski, Protektora Polskich Misji Zagranicznych, Raport z działalności Pol. Misji Kat. w Belgji od 15-I. do 15-X. $1926 \mathrm{r}$.

${ }^{12}$ Polska Misja Katolicka w Belgji, „Biuletyn Komitetu Opieki Kulturalno - Społecznej dla Wychodztwa Polskiego w Belgji”, październik 1926, s. 3; W. Pająk, Polacy w Belgji, „Polacy Zagranicą", 2 (1932) s. 16.

${ }^{13}$ AAG, APP, APWP, Belgia - Generalia, Dział III, Vol. I/44a, Ks. T. Kotowski Rektor P.M.K. w Belgji. Jego Eminencja Najdostojniejszy Ksiądz Metropolita Gnieźnieńsko-Poznański Prymas Polski, Bruksela, dnia 2/XII 1926 r. 
w Warszawie odpowiedni budżet mając zupełne poparcie Poselstw Polskich w Kopenhadze i Hadze”14 10 kwietnia 1927 r. Prymas Polski na prośbę „Poselstwa Polskiego w Hadze i Konsulatu w Amsterdamie oraz ulegając gorącym prośbą Polaków w Holandji rozszerzył kompetencję Polskiej Misji Katolickiej w Belgii również na Holandję"15 i Danię, a rektor PMK został mianowany jednocześnie rektorem PMK w Holandii i Danii. Z polecenia prymasa i w porozumieniu z Ministerstwem Spraw Zagranicznych i Urzędem Emigracyjnym w Warszawie rektor miał ,zapoznać się na miejscu z potrzebami religijnemi naszego wychodźstwa w tych krajach, odwiedzić ks. ks. Biskupów Holandji i Danji i w porozumieniu z nimi oraz z naszemi Poselstwami w Hadze i Kopenhadze przystąpić do organizacji opieki religijnej. Rzeczą najważniejszą byłoby wystaranie się o stałych kapelanów i sióstr Polek dla wychodźtwa" ${ }^{16}$. Sprawa zorganizowania stałej opieki religijno-kulturalnej w Holandii i Danii była również omawiana 29 kwietnia $1927 \mathrm{r}$. w Warszawie podczas posiedzenia „międzyministerialnej Komisji opieki nad Polakami Zagranicą"17.

Na podstawie pierwszych doświadczeń uzyskanych podczas objazdów misyjnych, Limburgji holenderskiej rektor PMK w Brukseli w piśmie do Kancelarii Prymasowskiej sugerował, by wyznaczyć jednego kapłana „dla obsługi duszpasterskiej naszych Polaków w Limburgji holenderskiej, których jest tam około 3 500. Ze względu na to, że Limburg holenderski z Limburgiem belgijskim stanowi jedno zagłębie węglowe, dla uniknięcia wysokich kosztów (floren holenderski $=14,50$ fr. belg.) należy księdza Polaka osadzić w Belgji w Hasselt"18.

Nie skorzystano jednak $\mathrm{z}$ tych sugestii, stałe duszpasterstwo na terenie Holandii zorganizowano w 1927 r. w Herlen. Ta placówka, z której obsługiwano polskie kolonie: Brunsaum, Hoensbroek, Kygolshoven, Heerler ${ }^{19}$, podlegała PMK w Brukseli. Jej stałym duszpasterzem został ks. Wilhelm Hoffman ${ }^{20}$.

${ }^{14}$ AAG, APP, APWP, Belgia - Generalia, Dział III, Vol. I/44a, Ks. Tadeusz Kotowski Rektor P.M.K. w Belgji, Do Jego Eminencji Najdostojniejszego Księdza Metropolity GnieźnieńskoPoznańskiego Prymasa Polski, Poznań, Nr 317/27.

${ }^{15}$ Kolonja polska w Holandji, „Biuletyn Katolików Polskich w Belgji, Danji i Holandji”, 8/12 (1927) s. 6.

${ }^{16}$ Opieka religijna nad Polakami w Holandji i Danji, „Biuletyn Komitetu Opieki KulturalnoSpołecznej dla Wychodztwa Polskiego w Belgji”, czerwiec 1927, s. 3.

${ }^{17}$ Opieka kulturalna nad emigracja polska w Belgji, „Biuletyn Komitetu Opieki KulturalnoSpołecznej dla Wychodztwa Polskiego w Belgji”, czerwiec 1927, s. 2-3. Komisja ta pracowała od września 1923 r., i w jej skład wchodzili przedstawiciele Ministerstwa Spraw Zagranicznych, Urzędu Emigracyjnego, Ministerstwa Oświaty, Ministerstwa Spraw Wewnętrznych.

${ }^{18}$ AAG, APP, APWP, Belgia - Generalia, Dział III, Vol. I/44a, Ks. Tadeusz Kotowski Rektor P.M.K. na Belgje, Holandje i Danje, Kancelarja J.Em. Prymasa Polski, Wydział Opieki nad Polakami Zagranicą, Bruksela, dnia, 7 czerwca 1927 r.

${ }^{19}$ AAG, APP, APWP, Belgia - Generalia, Dział III, Vol. I/44a, Sprawozdanie z działalności Polskiej Misji Katolickiej w Brukselii od 1/IX do 31/XII 1927 r., Bruksela, 20 lutego 1928 roku.

${ }^{20}$ J. Szymański, Sprawozdanie Wilhelma Hoffmanna MSF z 1929 roku o sytuacji Wychodźstwa polskiego w Limburgii holenderskiej, „Archiwa, Biblioteki i Muzea Kościelne”, 94 (2010) s. 331-338 . 
Wychodźstwo polskie było zniecierpliwione pozyskiwaniem przez rektora współpracowników do prowadzenia opieki duszpasterskiej wśród rodaków. „W zagłębiu Mons i Charleroi - napisał do ks. prymasa, ks. rektor - w 4-ch miejscowościach urządzono wiece ${ }^{21}$, gdzie niesłychanie ostro występowano przeciwko mnie [rektorowi] i Episkopatowi Polskiemu. Jedna z rezolucji głosi, że Misja Polska w Brukseli i Biskupi Polscy zaprzedali robotnika polskiego obcym i że prawdopodobnie rektor Misji w Brukseli został przekupiony przez Belgów i nie chce dopuścić kapłanów polskich do obsługi duszpasterskiej”22. Zdaniem ks. Kosibowicza do pracy duszpasterskiej w Belgii wystarczyło wydelegować 3 gorliwych kapłanów. „Jeden musi objąć część południowo-zachodnią, głównie departament Hainaut, drugi dep. Liège, gdzie komunizm szerzy spustoszenie wśród naszych górników, trzeci wreszcie część północną, zamieszkałą przez flamandów. Przy takiej obsadzie każda kolonia polska mieć będzie kapłana polskiego przynajmniej raz na miesiąc, zaś osady mniej liczne przynajmniej raz na dwa miesiące" $^{23}$.

W kwietniu 1927 r. do zorganizowania stałego duszpasterstwa wśród wychodźstwa polskiego w Belgii ks. prymas skierował dwóch stałych kapelanów ${ }^{24}$. Jednym z nich był ks. M. Szwabińskii ${ }^{25}$, a drugim ks. Cz. Wojciechowski ${ }^{26}$, który podjął pracę duszpasterską $\mathrm{w}$ Tournai. Stałe duszpasterstwo na terenie Belgii zostało zorganizowane w parafiach: Liège ${ }^{27}$, Cheratte, Montegné, Micheroux, Winterslag, Waterschei, Peronnes i Boussu-Bois ${ }^{28}$. Niemniej jak argumentował nieco później następca rektora Kotowskiego, ks. Władysław Kudłacik - w dalszym ciągu - ,jedną z poważniejszych czynności Rektora jest wyjaśnianie powodów mniej więcej rozumnych, mających przekonać rodaków, że ksiądz polski przyjechać nie może. Smutne to, ale prawdziwe"29.

Podobne działania - zorganizowania opieki duszpasterskiej wobec wychodźstwa polskiego w Danii przedsięwziął rektor Kotowski, z chwilą poszerzenia jego

${ }^{21}$ Cytaty z zachowaniem oryginalnego stylu, składni i ortografii.

${ }^{22}$ AAG, APP, APWP, Belgia - Generalia, Dział III, Vol. I/44a, Ks. Tadeusz Kotowski Rektor P.M.K. na Belgje, Holandje i Danje, Kancelarja J.Em. Prymasa Polski, Wydział Opieki nad Polakami Zagranicą, Bruksela, dnia, 7 czerwca $1927 \mathrm{r}$.

${ }^{23}$ AAG, APP, APWP, Belgia - Generalia, Dział III, Vol. I/44a, Ks. Kosibowicz T.J. W kwestji polskiej misji w Belgji. Ściśle poufne.

${ }^{24}$ Opieka religijna nad Polakami w Holandji i Danji, „Biuletyn Komitetu Opieki KulturalnoSpołecznej dla Wychodztwa Polskiego w Belgji”, czerwiec 1927, s. 3; por. Pająk, Polacy w Belgji, s. 16.

${ }^{25}$ Szymański, Duszpasterze Polonii i Polaków za granica, s. 72-74.

${ }^{26}$ Tamże, s. 157-158.

${ }^{27}$ J. Szymański, Relacja ks. M. Szwabińskiego z 1927 roku o sytuacji Wychodźstwa polskiego w okręgu Liège (Belgia), „Archiwa, Biblioteki i Muzea Kościelne”, 93 (2010) s. 291-299.

${ }^{28}$ AAG, APP, APWP, Belgia - Generalia, Dział II, Vol. I/44a, Ks. T. Kotowski Rektor P.M.K. w Brukseli, Sprawozdanie z działalności Polskiej Misji Katolickiej w Brukseli za kwartał od 1-go czerwca do 1-go września 1927 r.

${ }^{29}$ AAG, APP, APWP, Belgia - Generalia, Dział III, Vol. I/44a, Rektor P.M.K. Ks. Władysław Kudłacik, Do Kancelarji Prymasowskiej w Poznaniu, Bruxelles, le 16 listopada 1928 r. 
kompetencji i na ten kraj ${ }^{30}$. Bezpośrednio po świętach Bożego Narodzenia w $1926 \mathrm{r}$. udał się na dwutygodniowy objazd misyjny do Danii. Do raportu z objazdu dołączył: „Mapkę katolickiej Danji z oznaczeniem parafji, gdzie zamieszkują Polacy; Zeszyt z wycinkami z gazet; Paczkę fotografji, które dają pojęcie o charakterze i typie ludności polskiej w Danji" ${ }^{\prime 3}$.

W punkcie I. wspomnianego raportu - Stosunek ks. Wikariusza Apostolskiego w Kopenhadze i kleru do sprawy zorganizowania polskiej opieki religijnej w Danji napisal, że:

„Początkowo X. Wikarjusz Apostolski przyjął inicjatywę J. Em. Ks. Kardynała Polski z całą życzliwością, lecz po niejakim czasie sytuacja uległa zasadniczej zmianie.

W początkach lipca b.r. na konferencji zwołanej przez X. Wikarjusza Apostolskiego do Nestved w Zelandji w sprawie organizacji szkolnictwa katolickiego w Danji - grupa Misjonarzy władających językiem polskim, składająca się z księży narodowości niemieckiej i holenderskiej w liczbie 15 wystąpiła ze stanowczym protestem przeciw jakiejbądźkolwiek ingerencji Episkopatu i kleru polskiego do spraw duszpasterstwa w Danji.

Żeby należycie zrozumieć takie stanowisko kleru - napisał dalej rektor - należy nadmienić, że ostatnio w katolickich kołach misyjnych w Danji zarysowała się wyraźnie chęć nadania akcji misyjnej charakteru wyłącznie duńskiego. Wobec tego, że na ogólną liczbę 25 tysięcy katolików w Danji jest około 13 tysięcy Polaków i 5 tysięcy Niemców - kler pragnie przeprowadzić forsowną asymilację, podkreślając, że o ile nie da się zduńczyć Polaków i Niemców - Misja Katolicka w Danji będzie miała zawsze dla Duńczyków charakter obcy" .

Argumentację tę powtórzył również w punkcie VI. tegoż raportu - Dążność kół kościelnych do zasymilowania emigracji polskiej - wykazując, że „Postępy katolicyzmu wśród Duńczyków są znikome, wpływy Misjonarzy na społeczeństwo, mniej lub więcej oświecone - prawie żadne. Pozostaje jedyne wyjście - jak najszybciej zasymilować Polaków. W ten sposób uzyska się poważną podstawę do dalszej pracy misyjnej" . W kolejnym raporcie, by temu zapobiec, sugerował dokonanie podziału parafii na trzy grupy: 1 - parafie, gdzie Polacy stanowili 90 $\%$ wiernych; 2 - parafie, gdzie Polacy stanowili $50 \%$ wiernych i 3 - pozostałe. W pierwszej grupie parafii, Polacy powinni mieć nabożeństwa w każdą niedzielę i święta, a dzieci katechizację w języku polskim; w drugiej - 2 razy w miesiącu i w uroczystości obchodzone przez katolików, również z katechizacją w języku polskim; natomiast w 3 grupie parafii nabożeństwa odbywałyby się parę razy do roku, w zależności od możliwości sprowadzenia księdza mówiącego $\mathrm{w}$ języku polskim $^{32}$. Z uwagi na stanowcze stanowisko miejscowych duszpasterzy konse-

${ }^{30}$ Ks. J. Szymański, Z dziejów walki o dusze. Polskie władze kościelne i świeckie w trosce o rodaków w Holandii. Relacja z 1928 r., „Roczniki Historii Kościoła” 3/58(2011), s. 199-211.

${ }^{31}$ AAG, APP, APWP, Danja, Dział III/63, Raport ze stanu opieki religijnej nad emigracją polską w Danji, Rektor P.M.K. w Belgji X. Tadeusz Kotowski.

${ }^{32}$ Tamże, Raport ze stanu opieki religijnej i kulturalno-społecznej nad emigracją polską w Danji, Opracowany po jednomiesięcznym pobycie w Danji od 13-go sierpnia do 13-go września 1927 r. Rektora Polskiej Misji Katolickiej w Brukseli. 
kwentnie realizujących politykę zasymilowania Polaków, wpływy rektora PMK w Belgii zostały ograniczone.

Z dniem 2 sierpnia 1928 r., funkcję rektora PMK w Belgii objął ks. Władysław Kudłacik $^{33}$, dotychczasowy duszpasterz PMK we Francji ${ }^{34}$. W jego ocenie, w Belgii do objęcia posługą duszpasterską było „,15 kolonji większych (500-1200 dusz), 20 mniej więcej mniejszych i jeden ksiądz na to wszystko, chociaż odległość od Brukseli wynosi 60 do $240 \mathrm{~km}$. w różnych kierunkach. [...] Grozę sytuacji powiększa fakt dobiegania do końca układów o wpuszczeniu do Belgji, 6.000 Polaków, które powiększą liczbę rozproszonych kolonji. Zaznaczam, że dane dotyczą wyłącznie okręgu Rektora; pomijają zupełnie okręg ks. Szwabińkiego w Liège" ${ }^{35}$. W 1928 r. okręg Charleroi liczył „trzy kolonje większe i około 10 kolonji mniejszych, o których wiem od Polaków. Kolonje rozrzucone w okolicy Charleroi i wzdłuż linji kolejowej Charleroi - Namur. Okręg ogromnie zaniedbany przez misję a wysyłający emisariuszy socjalistycznych i komunistycznych na całą okolicę. [...] Ilość dusz polskich tego okręgu? Nie wiem i wiedzieć nie mogę i ani nawet przypuszczać, dopóki nie objadę kolonji. Trzy tysiące najmniej, licząc bardzo lekko"36. Podobnie przedstawiała się sytuacja w Limburgii belgijskiej, gdzie jak napisał było: ,pięć kolonji dużych z 4.000 do 5.000 dusz. Samo Winterslag ma około 800 pracujących w kopalni, co z kobietami i dziećmi każe obliczać liczbę Polaków na 1200 do 1500 . Eysden widziało księdza polskiego dwa razy, Beeringen ani raz ku zgorszeniu rodaków i kleru miejscowego. Okręg ten limburski liczy 5 kolonji dużych i kilka mniejszych, z których dotąd wiem o trzech [...]. Stosunkowo łatwym będzie umieszczenie księdza polsk. w Winterslag. Duchowieństwo belg. go żąda, jest możliwość otrzymania dla niego pensji rządowej belgijskiej, (przez Biskupstwo Liège - Leodjum). Jeden ksiądz będzie tam miał dużo zajęcia". Podobnie sytuacja przedstawiała się w okręgu Hainaut, który obejmował „4 kolonie większe, a ile mniejszych? Naprz.: Péronnes-les-Binche nazywa się zwykle jedną kolonją /Cité Marguerite/ okolica obejmuje-mówię o samym Péronnes-15 szybów, więc piętnaście kolonji, tymczasem w ewidencji mamy jeden [...] Codziennie prawie dowiaduję się o nowych kolonjach. Według dzisiejszych danych okręg liczy około 3.500 dusz, ale po zetknięciu się z zapomnianymi kolonjami liczba okaże się dużo większa. Mniejszych kolonji znam w tej chwili około 8, w nich miasto Mons z jakimiś 200 Polakami. Ze wszystkich stron żądają tam przyjazdu - rozumie się na niedzielę, by odprawić nabożeństwo - a ja jestem sam. [...] wkradł się tam indyferentyzm”. Podobnie sama Antwerpia „poza swoimi 15.000 Żydów polskich ma jednak dobrych kilkaset Polaków-katolików, zwłaszcza na przedmieściach /stocznie i fabryki/. Należy ich wyszukać i zająć się nimi" ${ }^{37}$.

${ }^{33}$ Szymański, Duszpasterze Polonii i Polaków za granica, s. 82-84.

${ }^{34}$ AAG, APP, APWP, Belgia - Generalia, Dział III, Vol. I/44a, Ks. Władysław Kudłacik, Rektor P.M.K., Wasza Eminencja!, Péronnes les Binche, dnia 8 sierpnia 1933 r.

${ }^{35}$ AAG, APP, APWP, Belgia - Generalia, Dział III, Vol. I/44a, Rektor P.M.K. Ks. Władysław Kudłacik, Do Kancelarji Prymasowskiej w Poznaniu, Bruxelles, le 16 listopada 1928 r.

${ }^{36}$ Tamże.

${ }^{37}$ Tamże. 
Sytuacja duszpasterska wśród wychodźstwa polskiego uległa zaostrzeniu. Rektor pisał wprost do Kancelarii Prymasowskiej: „,wydaje mi się rzeczą niezbędną nadesłanie 3-ch stałych kapelanów na Belgje i Holandje. W innym wypadku nie będę w stanie cośkolwiek zrobić i kompletnie się zdyskredytuje powaga a nawet celowość Misji”"38. W związku z tym, uważał nawet, że „Utrzymywanie Misji Kat. w Brukseli nietylko jest bezcelowe, ale wprost szkodliwe"39. Bezsilność działań ze strony PMK wzmagał narastający kryzys ekonomiczny, który pozbawiał środków materialnych nie tylko wiernych, ale przede wszystkim ich duszpasterzy. $\mathrm{Z}$ tego względu, 1 VIII 1930 r. rektor przeniósł siedzibę Misji do Péronnes ${ }^{40}$, gdzie otrzymał bezpłatny lokal do jej funkcjonowania ${ }^{41}$. Zamiana siedziby PMK, nie skutkowała zmianą problemów, którym na co dzień usiłował sprostać rektor ${ }^{42}$.

Pogłębiający się kryzys ekonomiczny, pozbawiał środków materialnych duszpasterzy polskich, którym zabierano dotację niezbędną do prowadzenia działalności duszpasterskiej ${ }^{43}$. $Z$ tego względu ks. Szwabiński zrezygnował z funkcji „kapelana polskich kolonji w okręgu górniczym Charleroi, [...] gdzie przebywa około 4400 ludności górniczej polskiej, w tem przeszło 2700 robotników, 700 rodzin 1000 dzieci” ${ }^{44} .1$ czerwca 1932 r. powrócił do kraju, pozostawiając w okręgu Charleroi około 5 tys. rodaków bez opieki duszpasterskiej ${ }^{45}$.

Kryzys spowodował też ograniczenie dotacji na rzecz PMK w Brukseli przez Ambasadę Polską (o 70\%) ${ }^{46}$. Pomimo, że rektor apelował o jej utrzymanie, ,gdyż - jak przewidywal - ponowne rozpoczynanie tworzenia nowych placówek dusz-

${ }^{38}$ AAG, APP, APWP, Belgia - Generalia, Dział III, Vol. I/44a, Ks. Tadeusz Kotowski Rektor P.M.K. na Belgje, Holandje i Danje, Kancelarja J.Em. Prymasa Polski, Wydział Opieki nad Polakami Zagranicą, Bruksela, dnia, 7 czerwca 1927 r.

${ }^{39}$ AAG, APP, APWP, Belgia - Generalia, Dział III, Vol. I/44a, Ks. Rektor T. Kotowski, Do Jego Eminencji Najdostojniejszego Xiędza Prymasa Polski, Bruxelles, le 14 lutego 1927 r.

${ }^{40}$ AAG, APP, APWP, Belgia - Generalia, Dział III, Vol. I/44a, Ks. Wład. Kudłacik Rektor P.M.K., Do Kancelarji Prymasa Polski /Wydział Duszpast. Zagran./ w Poznaniu, Bruksela, dnia 7 czerwca $1930 \mathrm{r}$.

${ }^{41}$ Archiwum Diecezjalne w Siedlcach, Akta Kurji Diecezjalnej Siedleckiej czyli Podlaskiej, Akta osobiste Ks. Władysława Ludwika Kudłacika 49/88, Tom I, (dalej: ADS, AKD, Akta osobiste Ks. Władysława Ludwika Kudłacika), s. 40.

${ }^{42}$ AAG, APP, APWP, Belgia - Generalia, Dział III, Vol. I/44a, Rektor Ks. Wład. Kudłacik, Do Kancelarji Prymasa Polski /Wydz. Duszpast. Zagran./ w Poznaniu, Péronnes-les-Binche, dn. 16 sierpnia 1930 r., 38, Chaussée de Nivelles; S. L[enartowicz], Wśród rodaków naszych na zachodzie Europy, „Polacy Zagranicą”, 4 (1931), s. 104.

${ }^{43}$ AAG, APP, APWP 1932-1939, Belgia - P.M.K. Budżet - Subwencje państw., Dział III, Vol. II/47, Ks. Wład. Kudłacik Rektor P.M.K., Do Kancelarji Prymasa Polski/Wydział Duszpast. Zagran./ w Poznaniu, Péronnes-les-Binche, 28 grudnia 1931.

${ }^{44}$ AAG, APP, APWP 1932-1939, Belgia - P.M.K. Budżet - Subwencje państw., Dział III, Vol. II/47, W. Strębski wz Dyrektor Departamentu MSZ, Do Kancelarji Księdza Prymasa Polski w Poznaniu, Warszawa, dn. 8 czerwca 1932.

${ }^{45}$ AAG, APP, APWP 1932-1939, Belgia - P.M.K. Budżet - Subwencje państw., Dział III, Vol. II/47, Ks. Zb[orowski], Do Ministerstwa S[praw] Z[agranicznych] Wydział Konsularny w Warszawie, 23/VI 1932.

${ }^{46}$ AAG, APP, APWP 1932-1939, Belgia - P.M.K. Budżet - Subwencje państw., Dział III, Vol. II/47, Ks. Wład. Kudłacik Rektor P.M.K., Do Kancelarji Prymasa Polski /Wydz. Duszpast. Zagran./ 
pasterskich po złagodzeniu kryzysu natrafi na duże trudności" ${ }^{47}$. Podobnie Urząd Emigracyjny, ze względu na bardzo znaczne obniżenie kredytu na opiekę nad emigrantami w roku budżetowym 1932/1933, był zmuszony zaprzestać jej subwencjonowania od 1 kwietnia 1932 r., chociaż rząd doceniał działalność Misji Katolickiej w Brukseli ${ }^{48}$.

$\mathrm{Z}$ relacji ks. rektora wynikało wówczas, że:

„Placówki w Hautrage i Troy (Liége) mają utrzymanie wystarczajace. [...] Placówka w Holandji utrzyma się również, gdyż ks. Hoffmann napisał mi wyraźnie, iż potrafi sobie znaleźć utrzymanie bez subwencji rządowej, jakkolwiek nie będzie to rzeczą łatwą. Placówki w Limburgji utrzymają się również, gdyż zarówno O. Wacław Van Ruythegen w Winterslag, jak i O. Justynian Vaunut w Zwartberg nie otrzymują od dłuższego czasu żadnej subwencji od Misji, a jednak czują się bardzo dobrze. Placówka w Charleroi jest sytułowana obecnie - po uzyskaniu pensji wikariuszowskiej dla Hautrage - najgorzej [...]. Pozostaje placówka w Péronnes. Otrzymanie osobnego domu odpowiadającego najzupełniej wymaganiom Rektoratu Misji było bezwzględnym sukcesem. Przy dalszym rozwoju Misji mogło w nim zamieszkać dwu lub trzech księży najzupełniej wygodnie. Nawet gdyby w przeszłości Misję mieli przejąć zakonnicy"49.

Bezradność wobec zaistniałej sytuacji rektor wyraził w piśmie, którego prosił „nie załączać do aktów”. Ponieważ, jak napisał: „Jeśli Poznań nie dałby mi chociaż 1000 . fr. belg $=250 \mathrm{zł}$ p. miesięcznie, to przeniósłbym się do Charleroi [...]. Szkoda jednak byłoby i placówki i domu w Péronnes, gdyż takiej sposobności trudno będzie znaleźć w przyszłości”. Jednocześnie zasugerował możliwość ewentualnego powrotu do $\mathrm{kraju}^{50}$.

Na skutek niechęci do obcokrajowców, wywołanej kryzysem, wśród kleru belgijskiego ujawniły się pewne uprzedzenia do Polaków. Proboszcz z Péronnes wprost zakazał polskich nabożeństw ${ }^{51}$ poza pierwszą niedzielą miesiąca. On ne

w Poznaniu, Péronnes-les-Binche, 28 stycznia 1932; ADS, AKD, Akta osobiste Ks. Władysława Ludwika Kudłacika, s. 40.

${ }^{47}$ AAG, APP, APWP 1932-1939, Belgia - P.M.K. Budżet - Subwencje państw., Dział III, Vol. II/47, Ks. Wład. Kudłacik Rektor P.M.K., Do Kancelarji Prymasa Polski /Wydz. Duszpast. Zagran./ w Poznaniu, Péronnes-les-Binche, 28 stycznia 1932.

${ }^{48}$ AAG, APP, APWP 1932-1939, Belgia - P.M.K. Budżet - Subwencje państw., Dział III, Vol. II/47, Ks. Wład. Kudłacik Rektor P.M.K. w Belgji, Do Kancelarji Prymasa Polski /Wydz. Duszpast. Zagran./ w Poznaniu, Bousecours, dnia 18 lutego 1932; tamże, Urząd Emigracyjny Nr 672/E.G., Do Kancelarji Prymasa Polski Poznań, Ostrów Tumski Nr. 1, Warszawa, dn. 5. marca 1932 r.

${ }^{49}$ AAG, APP, APWP 1932-1939, Belgia - P.M.K. Budżet - Subwencje państw., Dział III, Vol. II/47, Ks. Wład. Kudłacik Rektor P.M.K. w Belgji, Do Kancelarji Prymasa Polski /Wydz. Duszpast. Zagran./ w Poznaniu, Bousecours, dnia 18 lutego 1932.

${ }^{50}$ AAG, APP, APWP 1932-1939, Belgia - P.M.K. Budżet - Subwencje państw., Dział III, Vol. II/47, [Ks. Wład. Kudłacik Rektor P.M.K. w Belgji], Czcigodny Księże Kanoniku i nasz Szefie!, Bousecours, dnia 19 lutego 1932.

${ }^{51}$ „Pismem z dnia 8 lipca r.b. Ks. Jean Boucq proboszcz parafii św. Barbary w Péronnes Charbonnages zadecydował, że śpiew i kazanie polskie będzie tylko o godz. $9 \mathrm{w}$ pierwszą niedzielę miesiąca, a zakazał równocześnie modlić się i śpiewać po polsku we wszystkie inne niedziele i dni tygodnia. Les autres dimanches ou jours de la semaine, on ne priera ou chantera, qu'en francais". 
priera, qu en français ${ }^{52}$. Chociaż nabożeństwa dla Polaków nie przeszkadzały ni$\mathrm{komu}^{53}$. „Na skutek kryzysu - napisał rektor w piśmie do prymasa - ogarnęła Belgów tak wielka niechęć do obcokrajowców, że po raz pierwszy w dziejach liberalnej Belgji katolicki proboszcz zakazał się modlić po polsku i-po raz pierwszy w dziejach Kościoła polskiego cudzoziemski biskup nakazał polskiemu kapłanowi, jako komuniście wydającemu komunistyczne pismo, opuścić natychmiast obcy kraj, a nie tylko diecezję. Oba wypadki zdarzyły się w diecezji Tournai" ${ }^{54}$. Sprawą tą, rektor PMK usiłował zainteresować Nuncjaturę w Brukseli ${ }^{55}$. Napisał również do prymasa: „Uprzejmie proszę o interwencję Jego Eminencji jako mianowanego przez Rzym Opiekuna Duchownego wychodźców polskich w sprawie wyjątkowych trudności, jakie Misja natrafia w diecezji Tournai rządzonej przez J. Eksc. Ks. Bpa Gastona Antoniego Rasneur’a. [...] ksenofobja ograniczała się dotychczas na życiu społecznem, jednakże od jakiegoś czasu weszła w dziedzinę czysto kościelną i spowodowała pierwszy w Belgji zakaz modlenia się po polsku i pierwszy zapewne w życiu Kościoła Polskiego wypadek uważania i uznania kapłana polskiego za notorycznego komunistę, wydającego komunistyczne pismo; a w konsekwencji nakaz obecnego biskupstwa, by kapłan polski opuścił nie tylko diecezję, ale w ogóle obcy kraj i to natychmiast" ${ }^{96}$. Interwencja w powyższej sprawie okazała się skuteczna i przy okazji wyjaśniono, że „przeciwko nabożeństwom polskim nie podnosili zastrzeżeń Belgowie, lecz Włosi”"57.

Najlepiej status działalności duszpasterskiej duchowieństwa polskiego wśród rodaków w Belgii przedstawia relacja rektora Kudłacika: „Gdy popyt przewyż-

Jego podkreślenie. W załączeniu przesyłam listę nabożeństw zniesionych powyższym nakazem modlenia się po polsku, - chociaż - gdzieindziej /Beringen-Mines/ [kler belgijski] sam odprawia dla Polaków w każdą niedzielę osobną mszę św., byle tylko prze polski śpiew i modlitwę zachęcić ich do praktyk religijnych". AAG, APP, APWP, Belgia - Generalia, Dział III, Vol. I/44a, Ks. Wład. Kudłacik Rektor P.M.K. Odpis pisma z pieczęcią Kurii Biskupiej Podlaskiej, Péronnes-les Binche, 25 sierpnia 1933.

${ }^{52}$ AAG, APP, APWP, Belgia - Generalia, Dział III, Vol. I/44a, Ks. Wład. Kudłacik Rektor P.M.K., Wielce Czcigodny Ks. Prałacie [Zborowski] i nasz Szefie!, Péronnes-Binche, dnia 17 lipca 1933; ADS, AKD, Akta osobiste Ks. Władysława Ludwika Kudłacika, s. 44-45.

${ }^{53}$ AAG, APP, APWP, Belgia - Generalia, Dział III, Vol. I/44a, Ks. Wład. Kudłacik Rektor P.M.K. Odpis pisma z pieczęcią Kurii Biskupiej Podlaskiej, Péronnes-les Binche, 25 sierpnia 1933. „W załączeniu przesyłam listę nabożeństw zniesionych powyższym nakazem modlenia się po polsku"; tamże, Spis nabożeństw polskich zniesionych zakazem Ks. Prob. Boucq z PéronnesCharbonages, Odpis.

${ }^{54}$ AAG, APP, APWP, Belgia - Generalia, Dział III, Vol. I/44a, Ks. Władysław Kudłacik, Rektor P.M.K., Wasza Eminencja!, Péronnes les Binche, dnia 8 sierpnia 1933 r.; ADS, AKD, Akta osobiste Ks. Władysława Ludwika Kudłacika, s. 46.

${ }^{55}$ AAG, APP, APWP, Belgia - Generalia, Dział III, Vol. I/44a, Ks. Władysław Kudłacik, Rektor P.M.K., Do Kancelarji Prymasa Polski w Poznaniu, Péronnes les Binche, dnia 31 sierpnia 1933 r.

${ }^{56}$ AAG, APP, APWP, Belgia - Generalia, Dział III, Vol. I/44a, Ks. Wład. Kudłacik, Rektor P.M.K., Do Kancelarji Prymasa Polski w Poznaniu, Péronnes les Binche, 8 sierpnia 1933; ADS, AKD, Akta osobiste Ks. Władysława Ludwika Kudłacika, s. 48-49.

${ }^{57}$ AAG, APP, APWP, Belgia - Generalia, Dział III, Vol. I/44a, L. Chevalier vicaire général Evéché de Tournay, A Son Eminence le Cardinal Hlond, archevêque de Poznan, primat de Pologne, Le 20 septembre 1933. 
szał podaż ręki roboczej, patronowie górnictwa ustępowali przed naszemi żądaniami zabezpieczenia polskiego duszpasterstwa, chociaż czynili to niechętnie, za wyjątkiem p. Debilde'a z Hautrage. Stąd 6 placówek duszpasterskich polskich" 58. Skutki kryzysu ekonomicznego zaciążyły jednak na skali i metodach pracy duszpasterskiej. Niemniej w 1934 r. pod opieką PMK w Belgii działalność duszpasterska prowadzona była w: Péronnes; Souvret; Liège; Waterschei; Hasselt; Hautrage; Charleroi i w Heerlen (Holandia) ${ }^{59}$.

Ogólna sytuacja społeczno-polityczna nie sprzyjała jednak działalności duszpasterskiej polskich kapłanów. Narastały obawy, ,że pensje wikarjuszowskie kapelanów polskich naprawdę są zagrożone" i stąd apelowano do rządu polskiego o dotację rządową ${ }^{60}$. Na początku 1935 r. dyrekcje kopalń powiadomiły duszpasterzy polskich, że zmniejszają dotację polskich placówek duszpasterskich o 50\%, a ponadto rząd belgijski zmniejszył o $5 \%$ wynagrodzenie dla duchowieństwa ${ }^{61}$. Ponadto - od stycznia 1935 r. obniżono o połowę pensje wikariuszowskie i ,doszło do znacznej dewaluacji franka belgijskiego [o 1/3 ${ }^{\prime \prime 62}$. W tej sytuacji np. placówka duszpasterska w Hautrage - Etat swoją działalność opierała o dobrowolną dotację miejscowej kopalni oraz ,pensji Rządu Belgijskiego, złączonej zasadniczo ze stanowiskiem wikarjusza parafji belgijskiej w Quaregnon"63. Bezsilność wobec bieżących wyzwań duszpasterskich, a przede wszystkim stan zdrowia sprawiły, że rektor Kudłacik w sierpniu 1934 r. zwrócił się z prośbą o „odwołanie z duszpasterstwa zagranicznego i o zezwolenie na powrót do diecezji”"64. O trudnej sytuacji duszpasterzy polskich $\mathrm{w}$ tym czasie napisał w piśmie do Kancelarii Prymasa Polski:

„konfiguracja wychodźstwa polskiego w Belgji nie daje możliwości zapewnienia kapelanowi polskiemu dostatecznych dochodów. [...] W Belgji rodacy są

\footnotetext{
${ }^{58}$ AAG, APP, APWP, Belgia - Generalia, Dział III, Vol. I/44a, Ks. Władysław Kudłacik, Relacja w sprawie położenia katolickiego wychodźctwa w Belgji, Péronnes, dnia 18 grudnia 1933.

${ }^{59}$ AAG, APP, APWP, Belgia - Generalia, Dział III, Vol. I/44a, Ks. Wład. Kudłacik Rektor P.M.K. Do Kancelarji Prymasa Polski Wydział Duszp. Zagran. w Poznaniu, Péronnes les Binche, le 14 marca 1934.

${ }^{60}$ AAG, APP, APWP 1935-1939, Belgia - Generalia, Dział III, Vol. II/44, Ks. Wł. Kudłacik Rektor PMK, Do Kancelarji Prymasa Polski (Wydz. Duszp. Zagran.) w Poznaniu, Péronnes les Binche, 16 stycznia $1935 \mathrm{r}$.

${ }^{61}$ AAG, APP, APWP 1935-1939, Belgia - Generalia, Dział III, Vol. II/44, Ks. Ryszard Moskwa Duszpasterz Polski w Hautrage - Etat, Do Rektoratu Polskiej Misji Katolickiej w Belgji, Hautrage - Etat, dnia 14 I 1935.; Tamże, Ks. Wład. Kudłacik Rektor P.M.K., Do Kancelarji Prymasa Polski (Wydział Duszpast. Zagran.) w Poznaniu, Péronnes les Binche, 16 stycznia 1935 r.

${ }^{62}$ AAG, APP, APWP 1932-1939, Belgia - P.M.K. Budżet - Subwencje państw., Dział III, Vol. II/47, Ks. Wład. Kudłacik, Rektor P.M.K., Do Kancelarji Prymasa Polski (Wydz. Duszpast. Zagran.) w Poznaniu, Péronnes-les-Binche, le 8 kwietnia 1935; tamże, Ks. Zb[orowski], Do Ministerstwa Spraw Zagranicznych Wydział Konsularny w Warszawie, 11/V 1935.

${ }^{63}$ AAG, APP, APWP 1935-1939, Belgia - Generalia, Dział III, Vol. II/44, Ks. Ryszard Moskwa Duszpasterz Polski w Hautrage - Etat, Do Rektoratu Polskiej Misji Katolickiej w Belgji, Hautrage - Etat, dnia 14. I. 1935., Tamże, Ks. Wład. Kudłacik Rektor P.M.K., Do Kancelarji Prymasa Polski (Wydział Duszpast. Zagran.) w Poznaniu, Péronnes les Binche, 16 stycznia 1935 r.

${ }^{64}$ ADS, AKD, Akta osobiste Ks. Władysława Ludwika Kudłacika, s. 51.
} 
rozrzuceni. Jako „proboszcz” w Sallaumines [Francja] miałem 15000 Polaków w promieniu 3-ech kilometrów. Przyjeżdżając do Belgji przed siedmiu laty zastałem niewiele większą liczbę rodaków, ale rozrzuconych w jakichś dwustu parafjach, oddalonych od siebie po dwieście i 300 kilometrów. W takich warunkach duszpasterzowanie musi być bardzo kosztowne, a mało dochodowe. Zrozumiał to zresztą i Rząd Polski, dając tak długo dotacje dla placówek. System ten jest praktykowany w Belgji. [...] W Belgii wszystkie - ale to dosłownie wszystkie - placówki duszpasterskie polskie powstały w oparciu o dotację rządową, nawet kapelanje ojców flamandzkich w Limburgji. Działo się to dlatego, że wobec zazdrosnego stanowiska kleru belgijskiego, kapelan polski nie mógł liczyć na dochody za swe czynności kapłańskie, a dalej i dlatego również, że kler belgijski, sam płacony przez swój rząd, nie pojmuje kapelana polskiego inaczej, jak płaconego przez jego rząd. [...] Kler belgijski jest zabezpieczony materialnie i tak silnie oparty o najsilniejszą partję polityczną belgijską, że religia katolicka i polityczna partja nosi jedno miano i zupełnie się identyfikuje. [...] kler belgijski jest niezmiernie liczny i obejmuje cały legjon księży, żyjących wyłącznie z polityki partyjnej. Kler ten dysponuje całym szeregiem instytucyj, bardzo silnych finansowo, społecznie i politycznie. Dlatego też dufny jest w swoją potęgę i stanowisko społeczne i państwowe, a co za tym idzie, zazdrośnie dba o swoje przywileje i swój prestiż”65.

Do zmiany na stanowisku rektora PMK w Belgii doszło 25 czerwca 1935 r., „Kancelarja Prymasa Polski - powiadomiła ks. R. Moskwę - że Jego Eminencja powierza Mu Rektorat P.M.K. w Belgji na razie na rok jeden" ${ }^{\text {. }}$. Nowy rektor podjął bardziej zdecydowane działania. Poinformował Kancelarię Prymasa Polski, że ,W celu zwiększenia pracy i działalności duszpasterskiej na tutejszym terenie misyjnym staram się o zdobycie funduszów dla Pol. Mis. Kat. w Belgji w następujący sposób:

I. Zdobycie nowych wikarjatów belgijskich dla kapelanów polskich: 1) w Beeringen Limburgja - diecezja Liège; 2) w Charleroi lub okolicy - diecezja Tournay; 3) w Péronnes-les-Binche - diecezja Tournay; 4) w Brukseli - diecezja Maline.

II. Uzyskanie subsydjum z poszczególnych dyrekcji kopalń [...].

III. Uzyskanie subsydjum od Rządu Polskiego. Odpowiedni wniosek w tej ostatniej sprawie wpłynął do M.S.Z. w Warszawie za pośrednictwem Konsulatu w Brukseli o 2 tys. franków" ${ }^{67}$.

${ }^{65}$ AAG, APP, APWP 1935-1939, Belgia - Generalia, Dział III, Vol. II/44, Ks. Wł. Kudłacik Rektor PMK, Do Kancelarji Prymasa Polski (Wydz. Duszp. Zagran.) w Poznaniu, Peronnes les Binche, 16 stycznia $1935 \mathrm{r}$.

${ }^{66}$ Archiwum Archidiecezji Łódzkiej, Teczka personalna Ks. Ryszarda Moskwy - 511, Ks. Zborowski Szef Kncelarji Prymasa Polski, Odpis, Przewielebny ks. Ryszard Moskwa Rektor Polskiej Misji Katolickiej w Belgji w Hautrage Etat, Poznań, dnia 25 czerwca 1935 r.

${ }^{67}$ AAG, APP, APWP 1932-1939, Belgia - P.M.K. Budżet - Subwencje państw., Dział III, Vol. II/47, Ks. Ryszard Moskwa, Do Prześwietnej Kancelarji Prymasa Polski w Poznaniu, Hautrage-Etat, le 7 VIII 1935. 
Kancelaria Prymasa poleciła „sprawy duszpasterstwa polskiego w Belgji dostosować do istniejących możliwości finansowych"68. Rektor nie zrezygnował jednak ze swoich planów. W piśmie do Kancelarji Prymasa Polski napisał:

„Uprzejmie proszę o łaskawą aprobatę w następującej sprawie. Tutejsza emigracja polska w liczbie 24 tysięcy jest rozrzucona na terenie całej Belgji w 58 kolonjach. Wobec niedostatecznej liczby stałych księży kapelanów, na zebraniu odbytym w Louvain dnia 18 listopada 1935 r. zaprosiłem do współpracy wszystkich tutejszych Księży Studentów Polaków, którzy w miarę możności zaofiarowali się jeździć do poszczególnych kolonji polskich na niedzielę i święta" ${ }^{69}$. Jak przypomniał w imieniu Koła Polskich Studentów w Louvain ks. prymasowi, ks. Trochonowicz ${ }^{70}$ : „,począwszy od grudnia - cały basen Charleroi miał regularnie polskie nabożeństwa, w wielu innych ośrodkach był Ksiądz - Rodak na Boże Narodzenie i Wielkanoc, a prawie wszędzie uroczystość narodowa rozpoczynała się Mszą św. i kazaniem"’11.

Działania te wymusiły również konieczność ich dotowania przez Kancelarię Prymasa. Prosząc o dofinansowanie dla prowadzenia pracy duszpasterskiej wśród wychodźstwa polskiego, rektor napisał: „Wyjaśniam, że na terenie tutejszej Misji pracuje razem ze mną stale siedmiu księży kapelanów oraz ośmiu księży studentów”72, którzy angażowali się w ośrodkach duszpasterskich: „Hautrage, Quaregon, Bruksela - w każdą niedzielę; Chatelineau - dwie parafie, dwa razy miesięcznie; Maurage, Jumet, Anderlues, Marcinelle, Marchienne, Dampremy, Glain, Bossu raz na miesiąc; pomocniczookręgi Liège, Limburgia i Holandja"73. Ponadto ks. rektor przesłał do Kancelarii Księdza Prymasa informację (6 załączników) o skali wydatków związanych z funkcjonowaniem Misji ${ }^{74}$.

W kolejnym piśmie do Kancelarii Prymasa Polski rektor PMK podkreślał iż, rodacy w Belgii są dość dobrze zorganizowani, że działające organizacje są opar-

${ }^{68}$ AAG, APP, APWP 1932-1939, Belgia - P.M.K. Budżet - Subwencje państw., Dział III, Vol. II/47, Ks. Zborowski, Przewielebny Ks. Ryszard Moskwa Rektor P.M.K. w Belgji, Exp. 22 paź. 1935.

${ }^{69}$ AAG, APP, APWP 1932-1939, Belgia - P.M.K. Budżet - Subwencje państw., Dział III, Vol. II/47, Ks. R. Moskwa Rektor P.M.K., Do Prześwietnej Kancelarji Prymasa Polski w Poznaniu, Hautrage-Etat, le 25 XI 1935.

${ }^{70}$ Szymański, Duszpasterze Polonii i Polaków za granica, s. 146-147.

${ }^{71}$ AAG, APP, APWP 1935-1939, Belgia - Generalia, Dział III, Vol. II/44, Ks. Trochonowicz, Do Jego Eminencji Księdza Prymasa, Louvain 4 lutego 1935 r.

${ }^{72}$ AAG, APP, APWP 1932-1939, Belgia - P.M.K. Budżet - Subwencje państw., Dział III, Vol. II/47, Ks. R. Moskwa Rektor P.M.K., Do Prześwietnej Kancelarji Prymasa Polski w Poznaniu, Péronnes les Binche, 22 września 1936 r. Dochody duszpasterzy polskich w Belgii były mniejsze od zarobków górnika polskiego o 200 do 400 franków.

${ }^{73}$ AAG, APP, APWP 1932-1939, Belgia - P.M.K. Budżet - Subwencje państw., Dział III, Vol. II/47, Ks. Seweryn Wyczałkowski Prezes Koła [Księży Studentów], Do Rektora Misji Katolickiej Ks. Ryszarda Moskwy, Péronnes les Binche, Louvain, 22 września 1936. Zdaniem księży studentów „suma 800 fr. miesięcznie jest niezbędna dla normalnego prowadzenia powyższej pracy”.

${ }^{74}$ AAG, APP, APWP 1932-1939, Belgia - P.M.K. Budżet - Subwencje państw., Dział III, Vol. II/47, Ks. R. Moskwa, Do Prześwietnej Kancelarji Prymasa Polski w Poznaniu, Péronnes les Binche, 22 sierpnia $1936 \mathrm{r}$. 
te na zasadach polskich, narodowych i katolickich ${ }^{75}$. W opinii rektora do organizacji polskich należały tylko rodziny górnicze, które cechował wysoki poziom życia organizacyjnego tak co do ilości, jak i zrozumienia potrzeby organizacji ${ }^{76}$. Nie uszedł uwagi rektora fakt, iż: „wszystkie uroczystości państwowe, kościelne i zwyczajowe polskie, jak również wszystkie uroczystości Towarzystw (rocznice, poświęcenia sztandarów) odbywają się przy udziale księdza polskiego, [...]. Tam gdzie mają Polacy sposobność zwracają się całym zaufaniem do księdza polskiego, aby im załatwił sprawy dokumentów, interweniował w kopalni, w konsulacie lub u władz belgijskich. Organizacje starają się mieć księdza polskiego na zebraniach, na których zawsze proszą go o przemówienie" ${ }^{77}$. Autorzy wiadomości zamieszczonych w biuletynie przyznali, że „Środowiska, posiadające stale księdza lub, do których choć regularnie dojeżdża polski ksiądz, wyróżniają się wyższym poziomem moralnym, a co jest równie ciekawe i materialną sytuacją" 78 .

Pewne ożywienie życia religijnego nastąpiło w 1936 r., tym razem skonsolidowany wysiłek zarówno czynników kościelnych jak i państwowych okazał się korzystny dla duszpasterstwa polskiego ${ }^{79}$. Nie bez wpływu w tym względzie był odbywający się w Belgii Międzynarodowy Kongres Eucharystyczny oraz wizyta prymasa A. Hlonda w kilku polskich koloniach ${ }^{80}$. Tym bardziej, że każdy wyjazd kapłana do polskiego ośrodka, to nie tylko Msza św., kazanie, spowiedź, lecz także udział $\mathrm{w}$ miejscowych zebraniach organizacji polskich, odwiedzanie rodzin robotniczych ${ }^{81}$. Należy zauważyć, że w swych wędrówkach - co podkreślał rektor - „od czasu do czasu księżom udaje się „odkryć” /choć to wydaje się nieprawdopodobne/ nie znane nikomu nowe skupiska polskie, do których dotąd nikt jeszcze nie dotarł, mimo iż nieraz składają się one z kilkudziesięciu osób, a nawet w jednym wypadku grupa taka liczyła pareset dusz" $"$.

${ }^{75}$ AAG, APP, APWP 1935-1939, Belgia - Generalia, Dział III, Vol. I/44, Ks. R. Moskwa Rektor PMK, Do Prześwietnej Kancelarji Prymasa Polski w Poznaniu, Péronnes les Binche, 25 listopada $1938 \mathrm{r}$.

${ }^{76}$ AAG, APP, APWP 1935-1939, Belgia - Generalia, Dział III, Vol. II/44, Ks. R. Moskwa, Stan organizacji Polskich w Belgji, Hautrage - Etat 6 XI 1935 r.

${ }^{77}$ Tamże.

${ }^{78}$ Z katolickiego życia emigracji w Belgji, K[atolicka] A[gencja] P[rasowa] Nr. 32. /2432/, 8 lutego 1936 r., s. 3.

${ }^{79}$ T. Sopoćko, Święcone polskiej misji katolickiej w Belgji, K[atolicka] A[gencja] P[rasowa] Nr. 92./2492/, 20 kwietnia 1936 r., s. 2. „Z przyjemnością należy zanotować wystąpienie niektórych przedstawicieli władz polskich z wyraźną zachętą do życia religijnego i zapisywania się do katolickich stowarzyszeń. Podkreślamy ten szczegół tym chętniej, iż dotąd nie byliśmy przyzwyczajeni do takiego stanowiska. Tegoroczna akcja misyjna w okresie Wielkiej nocy była przeprowadzona z dużą energją. Księża nie zważając na trudy, odprawiali liczne nabożeństwa, wygłaszali nauki, spowiadali, udzielali Komunji św., święcili po domach. By nie pominąć żadnego większego skupienia, każdy z nich musiał objechać po kilka skupien, wykorzystując wszelkie środki lokomocji od roweru, tramwaju do samochodu włącznie".

${ }^{80}$ Le Primat de Pologne visite ses compatriotes à Pérones, „Gazette du Centre - La Louwiére” 6 IX 1936 r.

${ }^{81}$ Opieka moralna nad naszym wychodźstwem w Belgji, „Głos Narodu” - Kraków 23.08.1936.

${ }^{82}$ Sopoćko, Święcone polskiej misji katolickiej w Belgji, s. 2. 
Pomimo dotychczasowych zabiegów ze strony rektora PMK w Belgii nie zaszły istotne zmiany w organizowaniu opieki duszpasterskiej wśród wychodźstwa polskiego. W Limburgii nadal $\mathrm{w}$ większości kolonii polskich odprawiano miesięcznie tylko jedną mszę św. dla Polaków ${ }^{83}$. Niemniej, ze strony PMK w $1937 \mathrm{r}$. zabiegano o utworzenie stałej placówki duszpasterskiej w okregu Charleroi, dla kolonii polskich: Charleroi, Marcinelle, Chatelineau, Tailli-Pré, Gilli, Cuillet, Tamines, Farciennes, Jumet Houboide, Junut Malavé, Dampremy, Marchine au Pont, Monhan sur Sombre, Fontaine l'Eveque, Anderlues ${ }^{84}$.

W 1938 r. kapłani zaangażowani w działalność PMK w Belgii pełnili funkcję: 1. Ks. Ryszard Moskwa - rektora PMK i jednocześnie kapelana okręgu Centre; 2. Ks. Seweryn Wyczałkowski - kapelana okręgu Mons; 3. Ks. Jacek Przygoda kapelana okręgu Charleroi ${ }^{85}$; 4. Jan Oficjalski - kapelana okręgu Liège; 5. Ks. Wilhelm Hoffmann - kapelana w Holandii; 6. O. Justynian Vannut - kapelana w Limburgii; 7. O. Wacław Van Ruyteghem - kapelana w Limburgii. Kapłanów tych w ich posłudze w dalszym ciągu wspierali członkowie Koła Księży Studentów z Louvain: Maksymilian Rode, Roman Zientarski, Alojzy Nosal, Ambroży Lubik, Ferdynand Hupa, Kasjan Wolak, Marian Zwolski, Kazimierz Kłósak, Marian Boronowski i Stanisław Zdanowicz ${ }^{86}$.

Duszpasterze polscy niezależnie od funkcji pełnionej w PMK cały czas podlegali swoim biskupom ordynariuszom, którzy ich delegowali do tej pracy. Stąd w duszpasterstwie polskojęzycznym często następowała rotacja na zajmowanych stanowiskach. Spodziewając się odwołania m.in. ks. rektor Moskwa w liście do Kancelarii Prymasa Polski przedstawił dość obszernie sprawozdanie ze stanu Misji w 1939 r., wskazując że:

„1. Do obowiązków rektora należy odprawiać nabożeństwa oficjalne polskie w Brukseli. Odprawiać nabożeństwa i brać udział w uroczystościach i zebraniach dotyczących ogółu tutejszej emigracji. Starać się o utrzymanie placówek duszpasterskich polskich należących do tutejszej Misji. Starać się o koszta utrzymania dla poszczególnych księży kapelanów. Pokrywać koszta dojazdów księży studentów z Louvain do poszczególnych kolonji polskich na terenie Belgji i Holandji. Odprawiać lub w razie wyjazdu zapewnić odprawianie stałych nabożeństw w kaplicy polskiej w Péronnes za przynależny wikarjat. Odprawiać nabożeństwa stosownie do potrzeby w sąsiednich kolonjach należących do okręgu Centre, w którym jest siedziba rektoratu. Odbywać konferencje z księżmi kapelanami i utrzymywać z nimi stały kontakt. W okresie wielkanocnym urządzać rekolekcje w więk-

${ }^{83}$ AAG, APP, APWP 1935-1939, Belgia - Generalia, Dział III, Vol. II/44, Ks. R. Moskwa, Do Prześwietnej Kancelarji Prymasa Polski w Poznaniu, Péronnes les Binche, 10 IV 1937 r.

${ }^{84}$ AAG, APP, APWP 1935-1939, Belgia - Generalia, Dział III, Vol. II/44, Ks. R. Moskwa, Do Prześwietnej Kancelarji Prymasa Polski w Poznaniu, Péronnes les Binche, 9 IV 1937 r.

${ }^{85}$ Ks. Józef Pielorz, OMI, Ks Jacek Przygoda, Rektor PMK w Beneluksie w latach 1942-1947, „Duszpasterz Polski Zagranicą”, 50 (1999) nr 3, s. 402.

${ }^{86}$ AAG, APP, APWP 1935-1939, Belgia - Generalia, Dział III, Vol. II/44, Ks. R. Moskwa Rektor PMK, Do Prześwietnej Kancelarji Prymasa Polski w Poznaniu, Péronnes les Binche, 25 listopada 1938 r.; Zob. Szymański, Duszpasterze Polonii i Polaków, passim. 
szych skupiskach polskich i zapewnić spowiedź wielkanocną we wszystkich kolonjach polskich na tutejszym terenie.

Utrzymywać kontakt z Prześwietną Kancelarią Prymasowską w Poznaniu, z władzami polskimi w Brukseli, z władzami duchownemi i świeckiemi w Belgji, z dyrekcjami kopalń oraz z organizacjami polskimi na terenie Belgji.

2. Polska placówka duszpasterska okręgu Mons z siedzibą w Hautrage-Etat. Obowiązki tej placówki są: stała opieka nad wszystkimi Polakami zamieszkałymi w okręgu Mons. Kolejne w każdym miesiącu odprawianie nabożeństw w kilkunastu kolonjach okręgu Mons. Stałe odprawianie lub zapewnienie nabożeństw w Queregnon i w Hautrage-Etat za belgijską pensję wikarjuszowską w Queregnon. Opieka nad Polakami i organizacjami Polskimi w okręgu Mons. Pośrednictwo między Polakami a dyrekcjami kopalń i władzami belgijskimi.

3. Polska placówka duszpasterska okręgu Charleroi. Polaków jest około dziesięciu tysięcy zamieszkałych w przeszło 40 miejscowościach, z których w 16-tu odprawia się kolejno w każdym miesiącu nabożeństwa polskie. Obowiązki w stosunku do Polaków, organizacji polskich, dyrekcji kopalń i do władz belgijskich jak wyżej. (24 dyrekcje kopalń). Stałe odprawianie nabożeństw w miejscowości Taillis - Pré w niedzielę i święta.

4. Placówka duszpasterska polska w okręgu Liège. Około 8 tysięcy Polaków zamieszkałych w przeszło 30 miejscowościach. Nabożeństwa odprawiają się dla Polaków w 15 miejscowościach na zmiany. Obowiązki jak wyżej. Za pensję wikariuszowską obowiązek stałego odprawiania nabożeństw w St. Foy w Liège.

5. W Brukseli w każdą niedzielę i święta odprawia się nabożeństwa w kościele Ojców Redemptorystów.

6. Placówka duszpasterska w Winterslagu (Limburgja). Kolonie polskie Winterslag, Eysden, Beeringen i Heusden. Kapelanem jest Belg Ojciec Franciszkanin Wacław Van Ruyteghen, zamieszkały w Winterslag, Clinique. Od siedmiu miesięcy Ojciec ten jest chory po złamaniu nogi. W obowiązkach duszpasterskich zastępowali go dotychczas Księża Studenci z Louvain. [...]

7. Placówka duszpasterska w Waterschei (Limburgja). Kolonie Waterschei i Zwartberg. Kapelanem jest Belg Ojciec Franciszkanin Justynjan Vannut zamieszkały w Waterschei, Clinique [...].

8. Ponadto do tutejszej Misji przynależy polska placówka duszpasterska w Heerlen, 33 Oude Lindestr, Holandja. Obowiązki ma podobne jak księża kapelanji w Belgji. Odprawia nabożeństwa w 8 kolonjach.

9. Wreszcie do tutejszej Misji należy Koło Księży Studentów Polaków w Louvain. Księża ci stosownie do potrzeby dojeżdżają do poszczególnych kolonji polskich w niedzielę i święta"87.

${ }^{87}$ AAG, APP, APWP 1935-1939, Belgia - Generalia, Dział III, Vol. II/44, Ks. R. Moskwa. Sprawozdanie ze stanu Polskiej Misji Katolickiej w Belgji, Péronnes - Binche, 10 czerwca 1939 r.; J. Szymański, Organizacja opieki duszpasterskiej nad Wychodźstwem Polskim w Belgii w latach 1930-1947, „Archiwa, Biblioteki i Muzea Kościelne” 83(2005), s. 355-357. 
1 lipca 1939 r. nastąpiło przejęcie funkcji Rektora PMK w Brukseli przez ks. Jana Oficjalskiego ${ }^{88}$, kapłana diecezji kieleckiej. W Péronnes les Binche w siedzibie Misji, dotychczasowy ks. rektor R. Moskwa przekazał: Agendy Rektoratu ${ }^{89}$.

Dotychczasowy rytm pracy został jednak naruszony działaniami wojennymi. Polscy kapłani we własnym zakresie w porozumieniu $\mathrm{z}$ władzami diecezjalnymi usiłowali organizować posługę duszpasterską. Kiedy jednak działania wojenne przeniosły się na terytorium Belgii posługa duszpasterska duchowieństwa polskiego została ograniczona ${ }^{90}$. Dotychczasowy rektor ks. Oficjalski ze względu na swoje zaangażowanie na rzecz rodaków w maju $1940 \mathrm{r}$. musiał ratować się ucieczkąa1 .

Od 1942 r. cały ciężar odpowiedzialności za pełnienie posługi duszpasterskiej wśród wychodźstwa polskiego spoczął na ks. Jacku Przygodzie. Decyzją prymasa Polski A. Hlonda przebywającego wówczas w Lourdes został on mianowany rektorem PMK na Belgię i Luksemburg ${ }^{92}$.

\title{
THE IMAGE OF THE POLISH-SPEAKING CHAPLAINCY IN EUROPE BASED ON THE VISITATION CONDUCTED BY THE RECTOR OF THE POLISH CATHOLIC MISSION IN BELGIUM.
}

\begin{abstract}
Summary
The Catholic church in Poland undertook steps to provide optimal pastoral care for the Polish people abroad. These activities were formalized through the creation of the Polish Catholic Missions. The first Polish Catholic Mission was created in France (1922), next one in January 1926 in Belgium. This mission extended its power over Denmark, Holland (1927). The priests who successively held the office of Rector of the Polish Catholic Missions: T. Kotowski, W. Kudłacik and R. Moskwa organized pastoral, cultural, educational life among the Polish people and left, in the form of statements and reports, the descriptions of the condition and situation of the Polish emigrants abroad.

Translated by Aneta Kiper

${ }^{88}$ Archiwum Diecezjalne w Kielcach (dalej: ADK), Teczka personalna ks. Jan Oficjalski, sygn. $\mathrm{XO}-4$, życiorys.

${ }^{89}$ AAG, APP, APWP 1935-1939, Belgia - Generalia, Dział III, Vol. II/44, Protokół oddania agend Rektoratu Polskiej Misji Katolickiej w Belgji, Péronnes lez Binche 1.07.1939 r.

${ }^{90}$ Pielorz, Ks. Jacek Przygoda, s. 402; B. Wierzbiański, Polonia zagraniczna $w$ latach 19391946, Londyn 1946, s. 58.

${ }^{91}$ Ks. J. Pielorz OMI, Duszpasterstwo Polskie w rejonie Amay 1878-2003. La Pastorale Polonaise à Amay. Historia Duszpasterstwa Polskiego w rejonie AMAY - Flône. Diecezja Liège (Belgia) z okazji 25-lecia duszpasterstwa ks. dr Józefa Pilorza, omi, Liège - Amay, 8 grudnia 2003, s. 20; ADK, Teczka personalna ks. Jan Oficjalski, sygn. XO - 4, życiorys.

${ }^{92}$ Pielorz, Ks. Jacek Przygoda, s. 402.
\end{abstract}

